\title{
SARS, a challenge from the South
}

\section{When an epidemic threatens the affluent countries, the response is fast and well-funded.}

Sir - The next time a major health crisis strikes the world, there must be no doubt as to the motive behind a quick response from the North. This challenge from the South to the world's scientists can be met, for example, by implementing the suggestion of Gerald T. Keusch and Carol A. Medlin in their Commentary (Nature 422, 561-562; 2003) that a global health research network should be established to tackle emerging global crises.

Most scientific breakthroughs are generated in the North and they often neglect the problems that afflict most of the world's people (see, for example, Kofi Annan's "challenge to the world's scientists", Science 299, 1485; 2003). Within a week of receiving samples of the SARS virus in April, Canadian and US scientists independently announced its genome sequence (www.bcgsc.ca/bioinfo/SARS and www.cdc.gov/ncidod/sars/sequence.htm). On 15 May, scientists in Germany announced that available rhinovirus $3 \mathrm{CL}^{\mathrm{pro}}$ inhibitors might be modified for use in SARS therapy (K. Anand et al. Science doi:10.1126/science.1085658;2003).

These results should have an immediate impact on efforts to develop new and rapid diagnostic tests and antiviral agents for SARS. The speed of these praiseworthy efforts was necessary. Yet was their rapid success assured because northern interests were at stake?

Many southern countries are plagued by diseases whose mortality rates exceed that of SARS, for example Ebola virus and sleeping sickness, and the North's reaction to these has been comparatively retarded. This policy is shortsighted and ethically flawed. Although the relatively small size of the SARS genome may have facilitated its rapid sequencing, the recent announcements demonstrate how swiftly the North can react to a major epidemic.

Also in May, US President George W. Bush announced plans to spend more than $\$ 5.6$ billion over ten years to build a medical arsenal against biological terrorism. The magnitude of the sum and the relative tempo of the commitment are further indications that, if northern interests are threatened, massive funding can be realized virtually overnight.

There is a stark discrepancy between the standards of health in the developed and developing worlds. More than one billion people in the developing world have yet to benefit from the health improvements of the previous century that are taken for granted in the developed world. This is not to say that the North has completely ignored southern diseases (see Nature 421, 461-462; 2003). The sequencing of the malaria parasite genome (M. Gardner et al. Nature 419, 498-511; 2002) is an example of recognition by the North, in this case the US National Institutes of Health, that eradication of global health inequities is indeed a goal of genomics research.

However, the North must go further, by relaxing or cancelling crippling debt repayments and eliminating subsidies to northern farmers in order to aid southern exporters. Both measures will strengthen southern economies and, it is hoped, result in improved health and social conditions. The challenge for the North is to achieve these goals with the speed and commitment it demonstrated when it tackled SARS.

There are other, pragmatic reasons why the North should undertake these responsibilities. First, southern markets represent untapped growth potential for northern economies that will be frustrated by disease and poverty. Second, southern countries

offer a cheaper labour pool for the North. But illness stifles productivity. Third, neglected southern countries represent a dormant and latent security threat to the North in that illness and poverty beget desperation, instability and crime.

The emergence of SARS highlights the truth that diseases are not necessarily geographically exclusive. Global travel can facilitate the spread of deadly diseases from the South to the North within hours. It is also a warning that continued global health and wealth inequities can ferment new and deadly diseases.

At the same time, the dedication of northern resources to southern diseases must be met with genuine transparency by the South. Corruption, national pride and ego must take a back seat. Only international cooperation can prevent SARS and other emerging diseases from threatening us all. Mother Nature may be the ultimate bioterrorist.

\section{Jerome. A. Singh}

Howard College School of Law, University of Natal, King George V Avenue, Durban 4041, South Africa.

\section{Impact factors: target the funding bodies}

Sir - Peter A. Lawrence's suggestion (Nature 422, 259-261) for removing the politics from publication is that the wellestablished scientists should get together and stop over-valuing papers in popular journals. It will be a chilly day in hell before all the older scientists agree to change anything, much less something that currently benefits many of them. A different approach would be more realistic.

The urge to publish in well-known journals is often driven by money. Senior scientists seek top papers to ease the passage of their grants. Search committees are worried about making a huge investment in young scientists, so they seek top papers as a guarantee of future fundability. Tenure and promotions are strongly influenced by the funding that a candidate has managed to raise. The bodies that give grants usually love impact factors as a supposedly quantitative measure of the quality of science. This has inevitably led to overvaluation of the top journals themselves, rather than the science they contain.

We should therefore target the organizations that give grants, rather than hoping to persuade senior scientists to change their behaviour. If funding agencies set out to reward good science, as opposed to politically successful publications, then the distorted importance of the top journals would be lessened. Of course, productive scientists must be rewarded, so different criteria for achievement would be needed.

My action plan would be to persuade funding bodies to stop using journal impacts entirely, once applicants have been working independently for a few years. Instead, they should ask their referees to answer two questions. First, have this person's published papers been influential to the field? Have they provided the foundations for further discovery, or changed people's perceptions? Or were they predictable or (worse) incorrect? Second, is the applicant's newly published work likely to be influential in this way? Grant bodies have an advantage over journal editors in that they can judge papers retrospectively.

Answers of this sort would not remove the problem completely, as a high-profile paper would always carry better visibility than one in a little-read journal. However, explicit instructions to avoid impact factors - and instead concentrate on the value of past research - could only help to redress the balance.

\section{Robert Insall}

School of Biosciences, University of Birmingham, Edgbaston, Birmingham, B15 2TT, UK

Editor's note: See last week's issue for other Correspondence on this topic. 